УДК 636.09:616.98:57.083.33:578.835:599.731.1(477)

(C) 2014

Ситюк М. П., кандидат ветеринарних наук,

Безименний М. В., науковий співробітник

Інститут ветеринарної медицини НААН України, м. Київ

\title{
КАРТОГРАФІЧНЕ РАЙОНУВАННЯ ТЕРИТОРІЇ УКРАЇНИ ЗА РЕЗУЛЬТАТАМИ СЕРОЛОГІЧНИХ МОНІТОРИНГОВИХ ДОСЛІДЖЕНЬ ХВОРОБИ ТЕШЕНА У ПОПУЛЯЦІї ДИКИХ КАБАНІВ
}

\section{Рецензент - доктор ветеринарних наук В. П. Риженко}

Нведені результати серологічних моніторингових досліджень диких свиней у розрізі районів областей України відносно хвороби Тешена. За період 20012013 років досліджено 6840 зразків сироваток крові диких кабанів, відстріляних із територій 374-х районів усіх адміністративних областей України. Дослідження сироваток крові проводили мікрометодом реакиії нейтралізації у культурі клітин СНЕВ. Відбір сироваток крові від диких кабанів здійснювався у мисливські сезони й не передбачав стеоретипу постійного відбору зразків із певних районів територіі України. За результатами проведеного ретроспективного моніторингу визначено $і$ графічно зображено території районів областей Украӥни, де відбиралися та виявлені позитивні сироватки крові.

Ключові слова: хвороба Тешена, дикі кабани, серологічний моніторинг, картографічне районування.

Постановка проблеми. Інфекційну патологію сільськогосподарських тварин необхідно вивчати комплексно 3 дослідженням усіх ланок епізоотичного процесу та залученням дикої фауни. Проведення певних досліджень із-поміж диких тварин потребує витрат часу, залучення фахівців лісомисливських господарств, необхідності відстрілу особин тощо. Інфекційні хвороби диких свиней порівняно 3 домашніми вивчені мало й потребують визначення ролі в епізоотичному благополуччі галузі свинарства.

Аналіз останніх досліджень і публікацій, у яких започатковано розв'язання проблеми. Хвороба Тешена - вірусне захворювання свиней, що характеризується енцефаломієлітом і паралічами [3]. Вперше ензоотія хвороби була зареєстрована Трефні у 1930 році у містечку Tezen (Чехія) $[3,7]$. Відтоді захворювання реєструвалося у країнах Європи, Північної Америки, Південної Америки, Африки [1,8] та Австралії [7]. Хворіють свійські та дикі свині $[1,4,5,7]$. Частіше захворювання реєструється у віці 2-6 місяців, рідше - у 7-10 місяців [4].

Лабораторну діагностику хвороби Тешена здійснюють за допомогою реакції зв'язування комплементу (РЗК), імуноферментного аналізу (ІФА), реакції нейтралізації (РН) $[2,4,6,7]$ та реакції імунофлуоресценції (РІФ) [4, 2, 7]. За даними OIE, за ідентифікації антигена вірусу хвороби Тешена використовують індикацію вірусу у чутливій культурі клітин, РІФ, ІФА та полімеразну ланцюгову реакцію (ПЛР), а для серологічної діагностики - РН та ІФА $[2,8]$. Реакція нейтралізації рекомендована МЕБ для виявлення антигена та антитіл до вірусу хвороби Тешена [8].

У літературних джерелах зустрічаються дані щодо чутливості диких свиней до вірусу хвороби Тешена, зокрема, на території Свропи та Мадагаскару $[2,7]$. Однак у цілому увага дослідників стосовно хвороби Тешена у популяції диких кабанів $є$ незначною й потребує розширеного вивчення.

Мета дослідження: картографічно представити результати проведеного серологічного моніторингу диких кабанів відносно хвороби Тешена у розрізі районів областей України.

Завдання дослідження: дослідити сироватки крові диких кабанів щодо виявлення специфічних гуморальних антитіл проти вірусу хвороби Тешена за період 2001-2013 років. Представити показники чисельності досліджених сироваток крові у розрізі районів областей України з визначенням показників серопревалентності диких кабанів до вірусу хвороби Тешена.

Матеріал і методи дослідження. За період 2001-2013 років досліджено 6840 зразків сироваток крові диких кабанів, відстріляних із територій 374-х районів усіх адміністративних областей України. Дослідження сироваток крові проводили мікрометодом реакції нейтралізації у культурі клітин СНЕВ згідно з методикою [5]. Перещеплювану культуру клітин СНЕВ, виробничий атенуйований штам вірусу хвороби Тешена «Перечинський-642» 3 титром інфекційної активності $10^{9,5} \mathrm{lg}$ ТЦД ${ }_{50} / \mathrm{cm}^{3}$ та позитивну сироватку крові проти вірусу хвороби Тешена в титрі 1:1000 було одержано від завідувача лабораторії імунології та генетики IBM НААН академіка 


\section{ВЕТЕРИНАРНА МЕДИЦИНА}

НААН В. П. Романенка.

Відбір сироваток крові від диких кабанів здійснювався у мисливські сезони й не передбачав стеоретипу постійного відбору зразків із певних районів території України. Мінімальною одиницею за графічного відображення результатів серологічного моніторингу є район, оскільки у більшості супровідних документів були вказані лише лісомисливські господарства без даних про населений пункт. Мапи, що відображають результати серологічних досліджень, створено в ArcGIS 10.0 (ESRI, USA).

Результати дослідження. Проведений серологічний моніторинг хвороби Тешена у популяції диких кабанів на території України свідчить про наявність специфічних антитіл у їх популяції (рис. 1).

Відповідно до рисунку 1 , у період дванадцяти мисливських сезонів у моніторингові дослідження ввійшли всі адміністративні області України, а загальна кількість досліджених районів від наявних становила 374 (76,3\%). Теритоpiї 116 адміністративних районів не досліджувалися. У 292 районах $(59,6 \%)$ виявлено позитивні сироватки крові від диких кабанів у кількості 1364-х проб. Картографічно райони, де у диких кабанів були виявлені антитіла до вірусу хвороби Тешена, відображені по всій території України, однак більш зосереджені у північному, північно-західному, східному та частинах центрального та південного регіонів. Не можна стверджувати про відсутність або наявність серопозитивних до вірусу хвороби Тешена диких кабанів у районах, де не були відібрані зразки.

Показники частотного розподілу позитивних зразків до кількості районів наведені на рисунку 2.

Дані рисунка 2 вказують на те, що на території 82-х адміністративних районів України взагалі не було виявлено позитивних до вірусу хвороби Тешена сироваток крові від диких кабанів. На території 82-х районів виявлено лише по одній позитивній до вірусу хвороби Тешена сироватці крові. Надалі розподіл кількості позитивних сироваток до кількості районів був таким: 2/46, $3 / 43,4 / 28,5 / 14,6 / 12,7 / 11,8 / 11,9 / 8,10 / 8,11 / 7$, $12 / 2,13 / 5,14 / 3,15 / 1,16 / 1,17 / 2,18 / 2,20 / 1,21 / 1$, 24/1, 28/1, 37/1, 51/1.

Крім того було визначено та картографічно представлено райони, де періодично впродовж 12-и років виявлялися позитивні до вірусу хвороби Тешена дикі кабани (рис. 3).

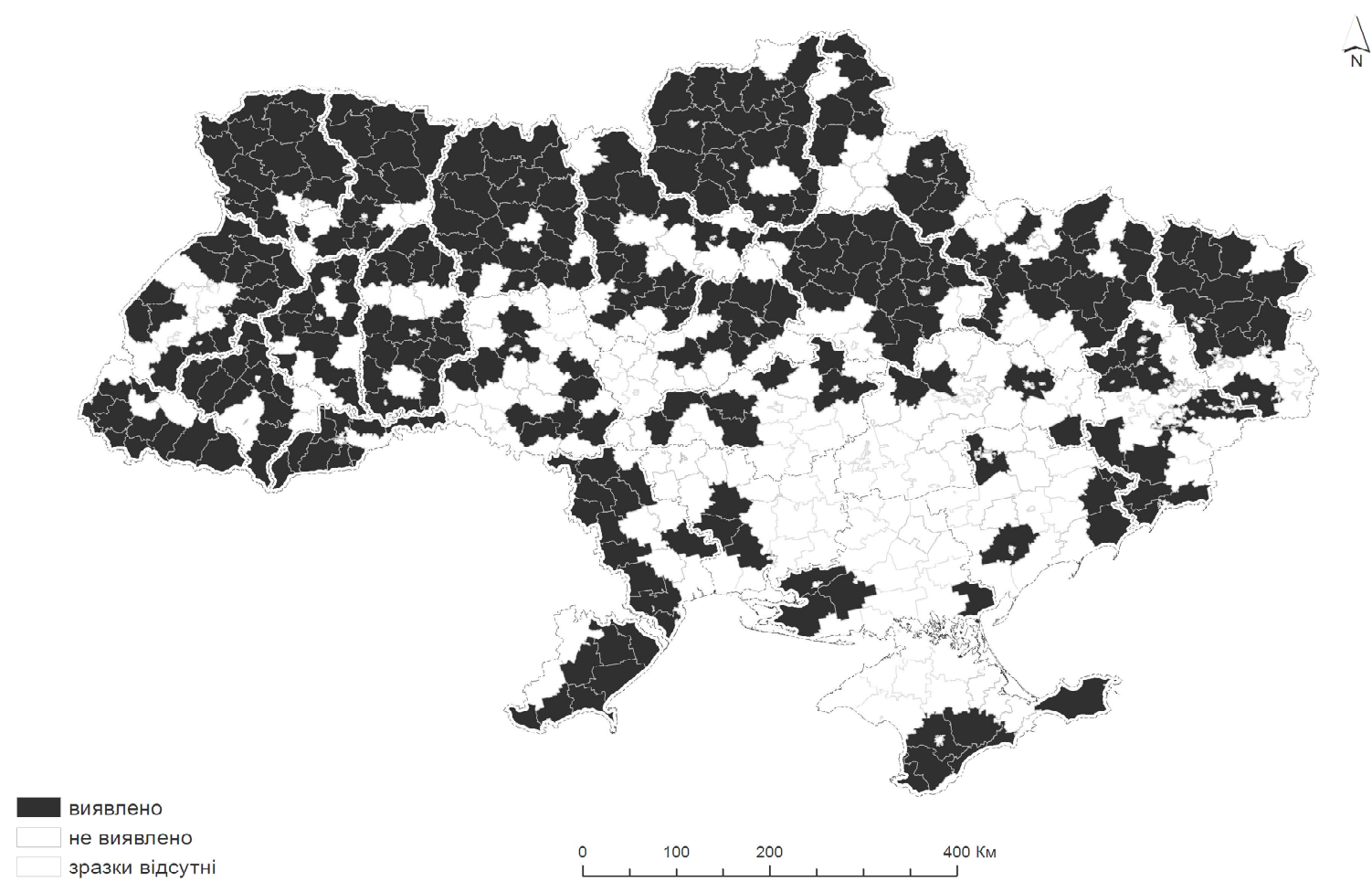

Рис. 1. Картографічне відображсення адміністративних районів Украӥни, де здійснювався серологічний моніторинг хвороби Тешена у популяції диких кабанів у період 2001-2013 років 


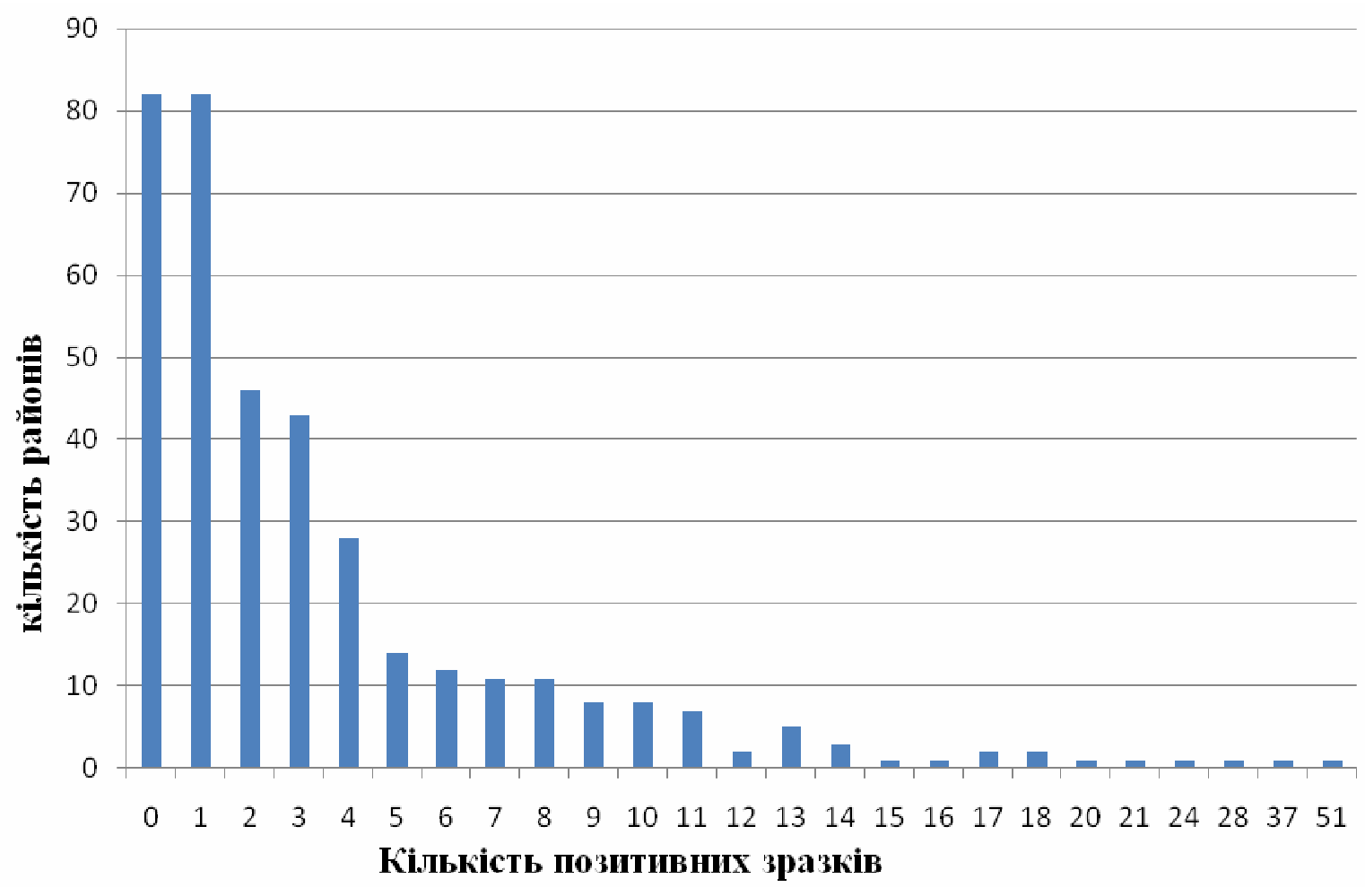

Рис. 2. Частотний розподіл кількості виявлених позитивних зразків до кількості районів

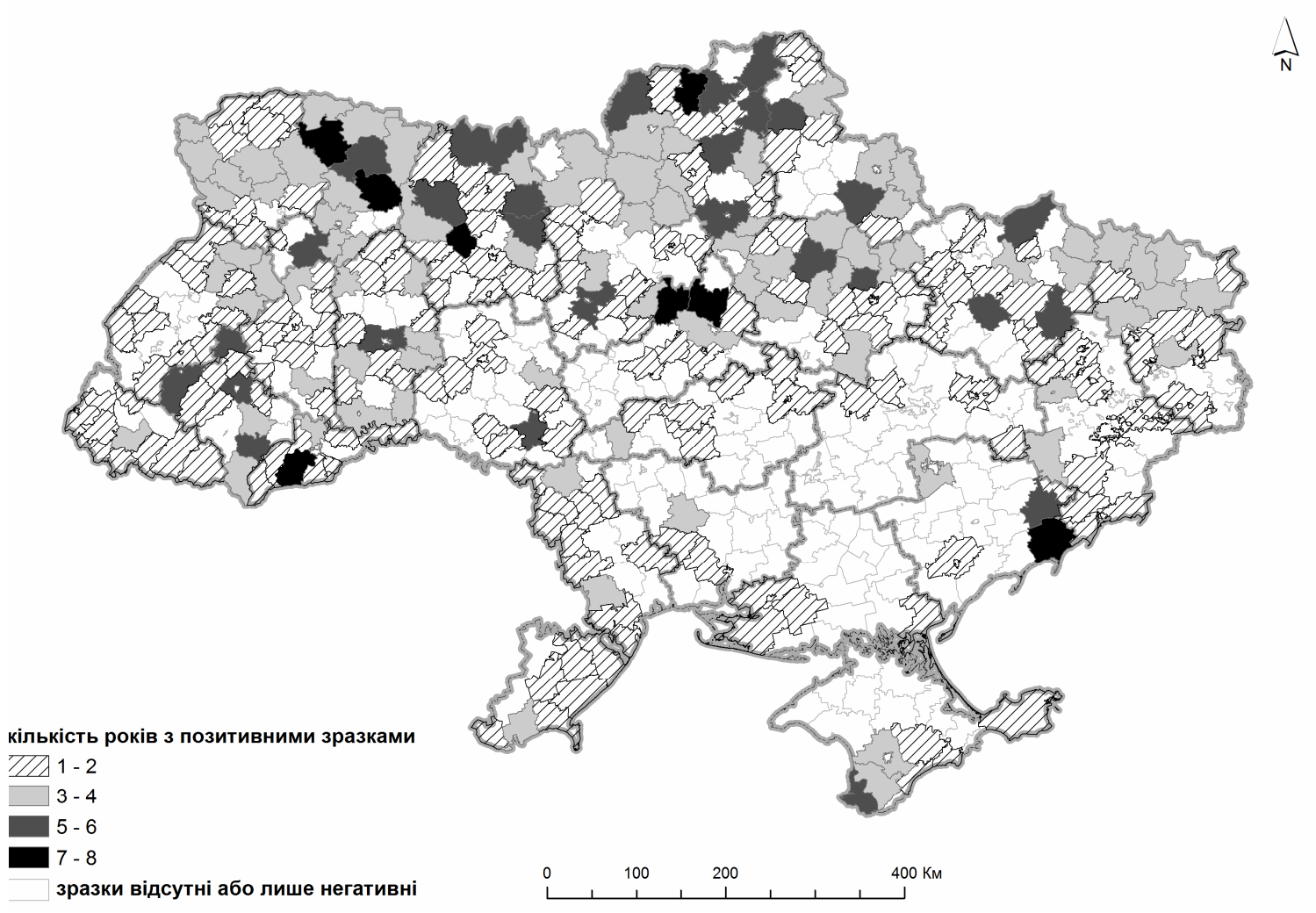

Рис. 3. Картографічне відображення адміністративних районів Украӥни, де періодично виявлялися позитивні до вірусу хвороби Тещена дикі кабани 


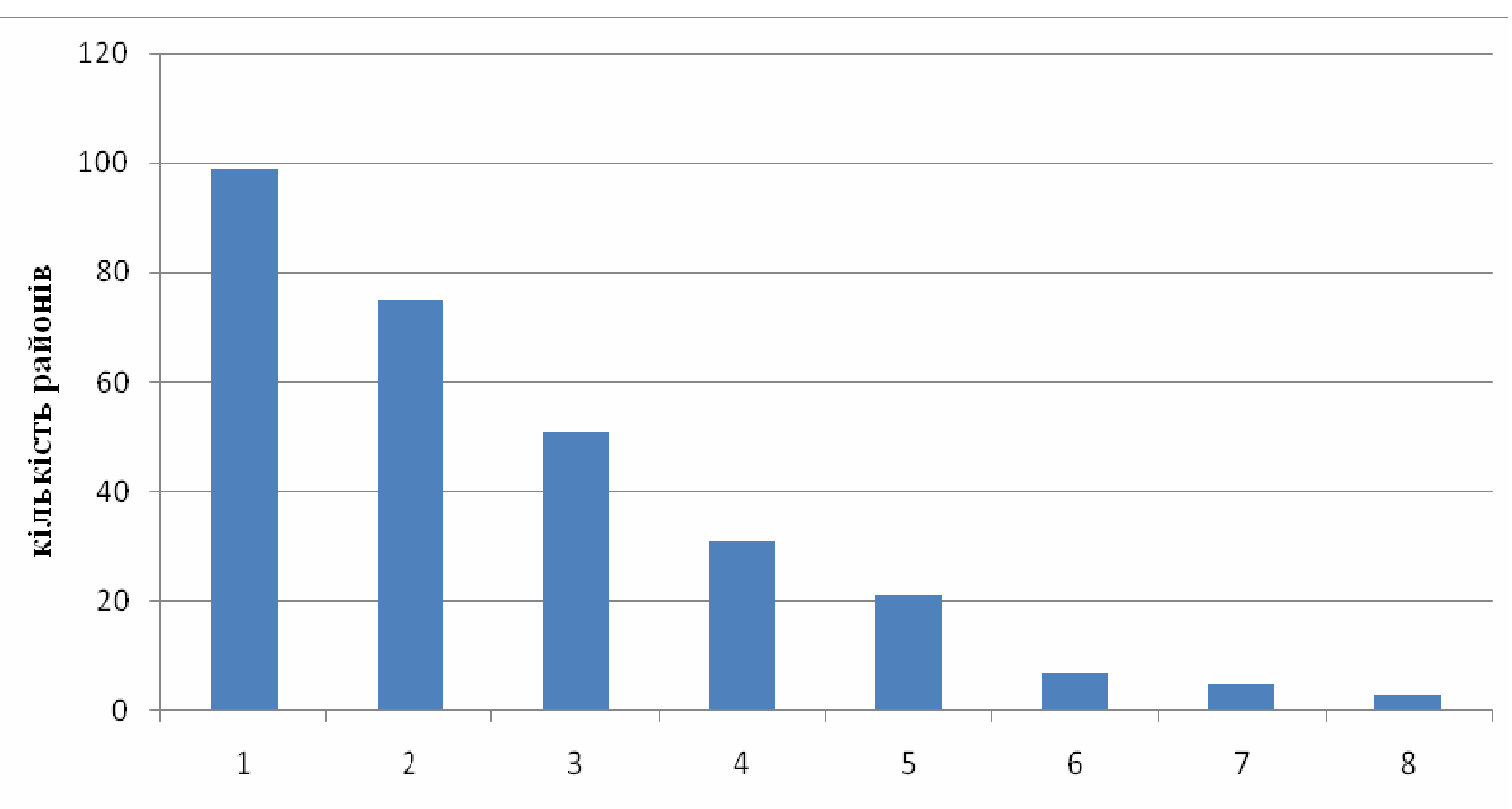

кількість років з позитивними зразками

\section{Рис. 4. Кількісні показники співвідночення досліджених районів до кількості років, де виявлені позитивні до вірусу хвороби Тешена дикі кабани}

Зображення рисунка 3 вказують на те, що за 12-річний період на територіях 292-х районів реєструвалися позитивні до вірусу хвороби Тешена дикі кабани. Переважно такі райони знаходяться на території північного, західного, східного, а також частині центрального і південного регіонів України. Проте на території України були райони у західному, східному, центральному й особливо у південному регіонах України, де не реєстрували позитивних до вірусу хвороби Тешена кабанів. Кількісні показники співвідношення досліджених районів до кількості років, де виявлені позитивні до вірусу хвороби Тешена зразки, наведені на рисунку 4.

Дані рисунка 4 свідчать про те, що на теритоpiї окремих районів України періодично впродовж семи років реєструвалися позитивні до вірусу хвороби Тешена дикі кабани. Кількісні показники співвідношення досліджених районів до кількості років, де виявлені позитивні до вірусу хвороби Тешена дикі кабани, були наступними: 99/1, 75/2, 51/3, 31/4, 21/5, 7/6, 5/7, 3/8.

Проведений ретроспективний серологічний моніторинг хвороби Тешена серед популяції диких кабанів вказує на інфікованість їх стад вірусом, оскільки в організмі цих тварин виявлялися специфічні гуморальні антитіла. Картографічно зображено 292 адміністративних райони, де були виявлені антитіла до вірусу хвороби Тешена у диких кабанів. Особливістю $є$ те, що ці райони знаходяться у різних регіонах на всій території України, однак більше зосереджені у північному, північно-західному, східному та частинах центрального і південного регіонів. Не можна стверджувати про відсутність або наявність серопозитивних до вірусу хвороби Тешена диких кабанів у районах, де не були відібрані зразки. Факт інфікованості вірусом хвороби Тешена диких кабанів на території України потребує більш поглибленого вивчення.

За даними [4], зараження здорових свиней може відбуватися за механічного перенесення вірусу в господарства людьми, тваринами, гризунами та птахами, а також із завезеними свинями-вірусоносіями. Хвороба Тешена у переважній більшості реєструється у приватному секторі, й саме завдяки господарській діяльності людини збудник може бути занесений і в ареали мешкання дикого кабана (ліси, заповідники, лісомисливські господарства тощо), або останні часто контактують із господарськими угіддями.

Все це цілком обгрунтовано доводить, що дикі кабани, як і домашні свині, можуть хворіти і бути носіями вірусу. Крім того в епізоотологічному аспекті поширення інфекції також залежить від епізоотичного стану сусідніх держав. Через міграційні шляхи дикі кабани заходять на чужі території, контактують з іншими стадами й інфі- 


\section{ВЕТЕРИНАРНА МЕДИЦИНА}

куються. Вивченню даної патології серед диких кабанів, на жаль, надається недостатньо уваги, а в державах, що межують з Україною, така інформація взагалі відсутня.

Висновки 1. Проведений ретроспективний серологічний моніторинг хвороби Тешена серед популяції диких кабанів на території України вказує на інфікованість їх стад вірусом, оскільки в організмі цих тварин виявлялися специфічні гуморальні антитіла.

2. Реєстрація серопозитивних до вірусу хворо-

\section{БІБЛІОГРАФІЯ}

1. Коломыцев A. A. ЭПизоотологический мониторинг и разработка средств иммунопрофилактики энтеровирусного энцефаломиелита свиней (болезни Тешена) / А. А. Коломыцев, В. М. Дубровин // Нейроинфекции: бешенство, губкообразная энцефалопатия крупного рогатого скота, Крейтцфелда-Якоба и другие прионные болезни; листериоз, болезнь Ауески, болезнь Тешена : материалы Междунар. науч.-практ. конф. 30-31 мая 2001 г. - Покров, 2001. - С. 160-165.

2. Романенко В. П. Ентеровірусні хвороби свиней / В. П. Романенко // Ветеринарна медицина України. - 2010. - № 12. - С. 11-13.

3. Романенко В. П. Хвороба Тешена (ензоотичний енцефаломієліт свиней) / В. П. Романенко // Ветеринарна медицина України. - 2009. - № 6. C. $15-17$.

4. Романенко В. Ф. Молекулярно-генетическая идентификация энтеровирусов свиней / В. Ф. Романенко // Ветеринария. - 2009. - № 12. - С. 8-14.

5. Романенко В. Ф. Рекомендации по диагнос- би Тешена диких кабанів, особливо в північному, північно-західному частинах східного та центрального регіонів України, відображає стаціонарність циркуляції збудника в їх популяції.

3. У перспективі майбутніх наукових досліджень необхідно продовжувати серологічний моніторинг хвороби Тешена 3 охопленням тих районів, де раніше не досліджувалися дикі кабани, а також зосередити увагу на виділенні 3 їх організму ізолятів вірусу з наступним вивченням антигенних властивостей.

тике и мерам борьбы с энзоотическим энцефаломиелитом (болезнью Тешена) свиней / В. Ф. Романенко, В. И. Сорока, О. Г. Прусс. - К., 1992. - $17 \mathrm{c}$.

6. Хвороба Тешена. Боротьба і профілактика / Ф. С. Вабіщевич, Ю. А. Собко, О. А. Панченко [та ін.] // Ветеринарна медицина України. 2009. - № 3. - С. 14-15.

7. Энтеровирусная инфекция свиней : porcne enterovirus infections // Вирусные болезни животных / В. Н. Сюрин, А. Я. Самуйленко, Б. В. Соловьев [и др.] - М. : ВНИТИБП, 1998. - С. 501507.

8. Teschovirus Encephalomyelitis (previously enterovirus encephalomyelitis or Teschen / Talfan disease) [Electronic recource] / World Organisation for Animal Health (OIE). - Mode of access : http://www.oie.int/fileadmin/Home/eng/ Health_standard s/tahm/2.08.10_TESCHOVIRUS_ENCEPH.pdf. Title from the screen. 